\title{
Remittances and Vulnerability to Poverty in Rural Mexico
}

\author{
Alejandro de la Fuente*
}

February 2008

\begin{abstract}
International remittances have been portrayed as the human face of globalization given their potential to alleviate poverty by directly increasing household income. Using a panel of rural households in Mexico from October 1998 to November 2000 this study assesses whether this is in fact the case. However, rather than examining whether transfers income would reduce future consumption poverty we asked if transfers are likely to reach people whose conditions are prone to worsen in the future. We used vulnerability to consumption poverty to quantify the extent to which risks and the more permanent disadvantages embedded in most rural livelihoods, can translate into future declines in well-being. We found, contrary to our expectations, a negative and statistically significant relationship between the remittance of transfers, including foreign remittances, and the threat to future poverty that rural households could experience.
\end{abstract}

Keywords: globalization, risk, vulnerability, poverty, private transfers, Mexico

JEL classification: D81, O15, I32

\section{Copyright (C) UNU-WIDER 2008}

*University of Oxford. Email: alejandro.delafuente@sant.ox.ac.uk

This is a revised version of a paper originally prepared for the UNU-WIDER project conference on The Impact of Globalization on the Poor in Latin America, directed by Professors Machiko Nissanke and Erik Thorbecke. The conference was organized in Rio de Janeiro, in collaboration with Pontifícia Universidade Católica do Rio de Janeiro, 23-24 September 2006.

UNU-WIDER gratefully acknowledges the financial contribution of the Finnish Ministry of Foreign Affairs to this project, and the contributions from the governments of Denmark (Royal Ministry of Foreign Affairs), Norway (Royal Ministry of Foreign Affairs), Sweden (Swedish International Development Cooperation Agency-Sida) and the United Kingdom (Department for International Development) to the Institute's overall research programme and activities.

ISSN 1810-2611 ISBN 92-9190- 061-6 


\section{Acknowledgements}

I am indebted to Stefan Dercon and Valpy Fitzgerald for their helpful comments on earlier versions of this draft. This paper has also benefited from comments by Machiko Nissanke, Erik Thorbecke, Sabina Alkire, Adrian Wood, and Proochista Ariana.

The World Institute for Development Economics Research (WIDER) was established by the United Nations University (UNU) as its first research and training centre and started work in Helsinki, Finland in 1985. The Institute undertakes applied research and policy analysis on structural changes affecting the developing and transitional economies, provides a forum for the advocacy of policies leading to robust, equitable and environmentally sustainable growth, and promotes capacity strengthening and training in the field of economic and social policy making. Work is carried out by staff researchers and visiting scholars in Helsinki and through networks of collaborating scholars and institutions around the world.

www.wider.unu.edu publications@wider.unu.edu

UNU World Institute for Development Economics Research (UNU-WIDER)

Katajanokanlaituri 6 B, 00160 Helsinki, Finland

Typescript prepared by Lisa Winkler at UNU-WIDER

The views expressed in this publication are those of the author(s). Publication does not imply endorsement by the Institute or the United Nations University, nor by the programmeme/project sponsors, of any of the views expressed. 


\section{Globalization, remittances, and poverty}

One of the most salient consequences of globalization has been the surge of remittances from developed to developing areas mediated through migratory processes. According to the World Bank's Global Economic Prospects 2006, in 1990 workers' remittances to middle and low income countries amounted to about US\$31 billion. Fifteen years later, they are estimated to have reached US\$167 billion. They have become a major source of financing for developing countries and are especially important in Latin America and the Caribbean (LAC), where they represent about 70 per cent of foreign direct investment (FDI) and are five times larger than Official Development Assistance (Fajnzylber and López, 2007).

In Mexico, migration to the United States has gained prominence during the last couple of decades leading to unprecedented flows of remittances to the extent that now the country tops the ranking of remittances in the world.1 Worker remittances have continued to exceed revenues from tourism since 1998. In 2005, tourism garnered US $\$ 8.5$ billion, while remittances hovered around US\$20 billion. Likewise, remittances have already surpassed FDI for the first time in the recent past. In 2005, remittances outperformed the US\$19.7 billion sent in FDI.

If remittances have become the human face of globalization as migrants commit portions of their income to help their households in the host and the home country (Orozco, 2002), then - the argument goes - given that they often go to poor households and directly increase these household's level of income, they could become a massive

Figure 1. Foreign Currency Flows into Mexico

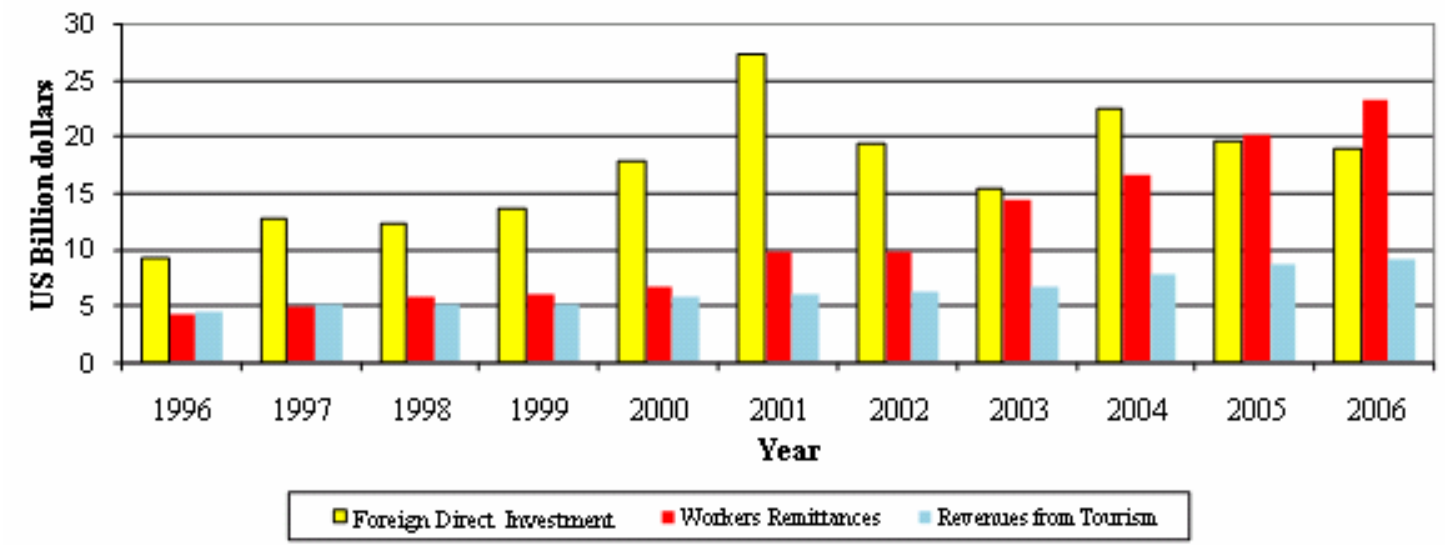

Source: Bank of Mexico

1 Migration from Mexico to the United States has always been a double-edged sword. Some perceive the increasing flows of people as evidence of an increased interdependence between complementary economies in an era of economic integration while others interpret the same experience as a painful reminder of the exclusionary nature of the globalization friendly development model embraced by the country since the $1980 \mathrm{~s}$, which has forced many to the other side of the border. 
resource transfer mechanism, able to bring down poverty levels. ${ }^{2}$ Following this logic it has become commonplace to assume that a higher and more regular reliance on foreign transfers represents an opportunity for agricultural households to become less vulnerable to poverty and risks.

Nevertheless, those in more need are not always the ones that receive remittances (Goldstein et al., 2004), either because they go to better-off households or simply because not all poor households with social networks receive support during hardship. When there is no immediate need to cope with risks, the activation of remittances would also not necessarily be aligned to the needs faced by the recipient even if there is a permanent risk of staying poor or becoming poorer due to the household's own structural characteristics, but rather depend on who is the net provider of insurance, relative risk preferences, and relative bargaining power (Lucas and Stark, 1985). According to Lucas and Stark (1985) when the migrant is a net provider and perceives no reason to continue doing so (i.e., if the recipient household is poorly endowed, has limited command over the migrant and thus weak negotiating power to maintain $\mathrm{him} / \mathrm{her}$ in the contract) then he/she might be tempted to stop sending remittances. We therefore anticipate that the existence of national and transnational support networks cannot be taken for granted as an effective tool to mitigate poverty since their activation depends in part on the type of risks faced, the constraints imposed on the donor by its own circumstances and the presence of non-altruistic motivations.

Based on these counter arguments we reconsider the presumption that transfers in rural areas reach the 'right people' from a poverty reduction perspective and ask whether transfers actually reach those rural households in Mexico whose conditions are likely to worsen in the future. We are tempted to consider this to be the case given that our group of households is located in extremely poor high risk agrarian communities with limited access to formal insurance mechanisms (García-Verdu, 2002) rendering more likely a system of wide reciprocity extending beyond the family. 3

We consider the relationship between poverty and remittances within a dynamic context that takes into account the impact that risk-induced fluctuations and other more permanent disadvantages at the household and community level can have on the future welfare status of households (as assessed through consumption) and the subsequent implications this could have for the mobilization of transfers. Households can send money because we assume implicitly that their members, including the permanent

2 This argument has led to perceive remittances as one of the factors behind the recent drop in poverty rates in Mexico (Lanjouw, 1998; Székely and Rascón, 2005) and other LAC. According to the World Bank's Development Impact of Remittances in Latin America report world cross-country and microbased estimates indicate that, on average, an increase in one per cent point in the ratio of remittances to GDP would be associated with a decline in poverty of about 0.4 per cent (Fajnzylber and López, 2007). In a similar vein, a recent study by the same institution on south-eastern Mexico (Wodon et al., 2002) attributed a two point reduction in the income poverty rates of Guerrero and Oaxaca to local and foreign remittances by a pure income transfer effect, an impact of similar scope to that of the public transfer programmes Procampo and Oportunidades (Progresa).

3 In agrarian economies, there is a wide range of social arrangements operated through the idea that peasants share a common subsistence ethic that forces each other to engage in a wide system of reciprocity to assure a minimum satisfaction of needs. Social insurance mechanisms such as forced generosity, communal land and work-sharing are thus present against 'normal' risks (i.e., family land to dry or to wet for resisting a harvest, breadwinner falling ill at transplanting or harvest time, etc.) though not for collective disasters through a system of social exchange and reciprocity (Scott, 1976). 
migrants living abroad as former members, have a good knowledge of the process that leads to consumption outcomes. Even if they ignore the state of the world that will prevail in each point of time they can recognize welfare deteriorating conditions or events which could lead to future poverty and respond accordingly. Once the household specific estimates for future poverty are obtained we will look at the main features of transfers and those engaged in them in our sample. The next section will bring both pieces of information together to create various models on the incidence of transfers and their levels. The results of these models are then discussed before concluding.

\section{Vulnerability}

\subsection{Definition}

Vulnerability in this work is understood as the magnitude of the threat of future poverty that a household experiences at a given point in time (Calvo and Dercon, 2005). This definition of vulnerability makes it different, but closely related to the concept of poverty. Poverty measures are generally fixed in time, making poverty itself essentially a static concept. By contrast, vulnerability here aims to identify households at risk of welfare shortfalls in the future based on their current standing. In this sense, it is an ex ante forward looking measure. The threat component in the definition alerts us about the centrality of risk. Given that risks refer to possibly occurring events that can damage well-being, it is their presence that is associated with a threat to welfare until they materialize or vanish. Finally, the threat of poverty is experienced in very different ways by each household, according to its own human and physical stock as well as the type of risks it faces. This leads to varying welfare circumstances across households that will be represented in the magnitude of the threat. Hence this magnitude is compounded by the likelihood of becoming poor(er) and the depth of such impact. The measure takes the following form

$$
\mathrm{V}(\mathrm{p}, \mathrm{c}, \mathrm{z})=\sum_{\mathrm{h}=1}^{\mathrm{n}} \mathrm{p}_{\mathrm{h}} \mathrm{v}\left(\mathrm{x}_{\mathrm{h}}\right), \text { where } \mathrm{x}_{\mathrm{h}}=\frac{\tilde{\mathrm{c}}_{\mathrm{h}}}{\mathrm{z}}
$$

where $\mathrm{v}($.$) is a monotonic decreasing and convex function, \mathrm{z}$ is a standard poverty line, $c$ denotes the vector containing different states of the world for the relevant welfare outcome (in this case consumption per capita) and $\mathrm{p}$ is the probability of each occurring. $\tilde{\mathrm{c}}_{\mathrm{h}}=\min (\mathrm{z}, \mathrm{c})$ represents the standard characteristic of poverty measures under which values above the poverty line do not get any weight, in order to satisfy the focus axiom. ${ }^{4}$ By using $\tilde{c}_{\mathrm{h}}$ we then ensure that $\mathrm{c}_{\mathrm{h}}$ has no effect on vulnerability when $\mathrm{c}>\mathrm{z}$. Therefore, $\mathrm{x}_{\mathrm{h}}$ becomes a ratio of coverage of minimal needs (assuming that $\mathrm{z}$ conveys a reliable monetary value of the cost of obtaining a basket of goods and services considered adequate to satisfy a group of basic needs) that takes values between 0 and 1 and $\mathrm{v}(\mathrm{x})$ is its transformation to make it appropriate for the desired feature of an increase (decrease) in risk with its corresponding upward (downward) shift in

4 The focus axiom property requires concentrating only on those outcomes that are likely to be poverty threats. 
vulnerability. Given the need to stress the role of risk in the vulnerability function one can rewrite (1) in the following way

$$
\mathrm{V}_{\alpha}(\mathrm{p}, \mathrm{c}, \mathrm{z})=1-\mathrm{E}\left[\mathrm{x}_{\mathrm{h}}^{\alpha}\right] \text {, where } 0<\alpha<1
$$

Here $\alpha$ can be interpreted as the coefficient of relative risk aversion, where $\mathrm{x}_{\mathrm{h}}$ is defined as before and takes the form of an exponential function to fulfil the condition of risk increasing when the mean value spreads from the middle to the tails. Therefore this normalized ratio of minimal needs obtained for each household by dividing total consumption per capita by the poverty line becomes adjusted by the risk aversion parameter. The expectations operator will summarize the weighted ratios by attaching probabilities to their occurrence. Finally, one minus this adjusted needs ratio transforms it into a monotonically decreasing convex function which achieves again the desired nature of risk-sensitivity in the measure of vulnerability. 5

\subsection{Measurement}

From (2) one could break the estimation of vulnerability into two steps. First, and most importantly, one has to estimate an ex ante probability distribution of future consumption for each household $\mathrm{E}(\mathrm{Fc})$. This is because at the core of the notion of vulnerability lies the possibility that from the current standing of a household in time $t$, one could say something about its welfare prospects in $\mathrm{t}+1$. This $\mathrm{E}(\mathrm{Fc})$ distribution will be formed by a series of potential consumption values $\left(\tilde{c}_{h}\right)$ which will provide the raw material for coming up with the desired outcome against which one could assess the welfare level of each household.

Once the distribution of future consumption has been estimated, most of the decisions that will shape the form of the statistic created $\left(\mathrm{V}_{\alpha}\right)$ come into effect. These choices could be taken at the outset but are only applied now. They include the definition of the consumption poverty line $\mathrm{z}$ along with the value of the risk aversion parameter for each household $\alpha$.

Considering we want to say something about future consumption starting from our baseline in October 1998, the full methodology (laid out in de la Fuente, 2005) allows us to end up with estimations for every household in both November 1999 and 2000. In Figure 2 we observe that the levels of vulnerability rose steadily throughout this interlude for most households, including those with relatively low levels of exposure to poverty threats, from an average level of vulnerability of 0.353 in November 1999 to 0.366 by the end of 2000 .

5 The measure of vulnerability presented at the individual level can be summed over all households to convey a measure of aggregate vulnerability in the following way: $V(p, y, z)=\Sigma_{i}^{n}=1 V_{i}(p, y, z)$, where $\mathrm{n}$ is the total number of households. 
Figure 2 Vulnerability to Poverty

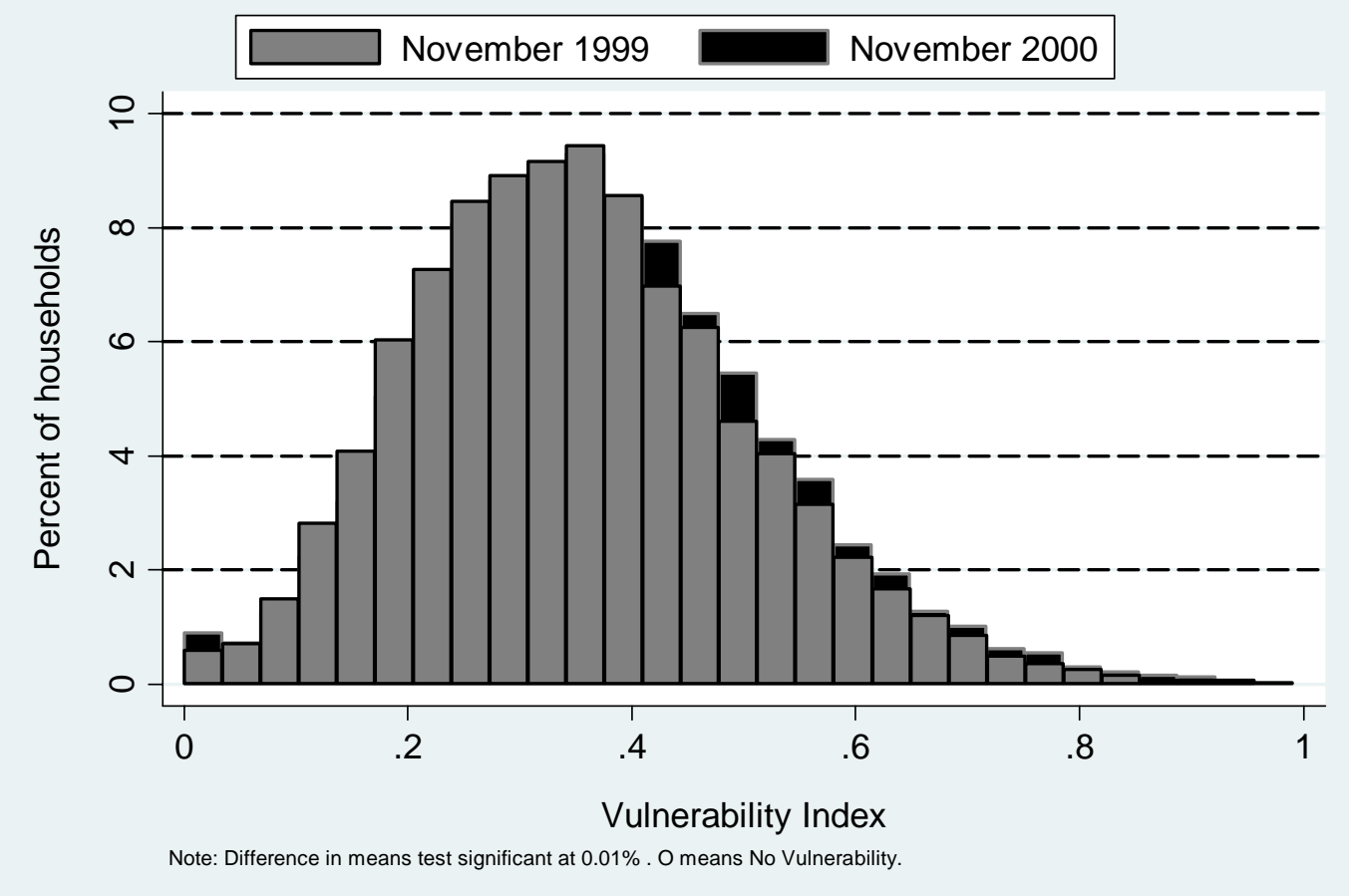

\section{Data}

The main source of information for this paper comes from a group of 18,893 households located in 506 localities across seven states of Mexico: Guerrero, Hidalgo, Michoacán, Puebla, Querétaro, San Luis Potosí and Veracruz. They comprise some of the most deprived rural communities in the country and were set to be the prime target of the poverty alleviation Programme in Education, Health and Nutrition (Progresa and since 2002 Oportunidades).6 A broader sample was initially surveyed in August 1997 (Encuesta de Características Socioeconómicas de los Hogares or ENCASEH) at the onset of the programme to determine its beneficiaries. Subsequently, a series of socioeconomic household surveys (Encuesta de Evaluación de los Hogares or ENCEL) were carried out approximately every six months for a period of three years (from March 1998 to November 2000) with the purpose of providing inputs for assessing the programme's performance. These successive questionnaires plus a new round undertaken in March 2003 make up a total of seven rounds of information for the same group of households. These surveys were supplemented with questionnaires from the localities where households reside (Cuestionario de Localidad or ENCELLO).

6 Progresa was introduced in 1997 and re-launched as Oportunidades in 2002. Its basic objective is to improve the education, health and nutrition of poor families, particularly children and their mothers. In addition to nutrition supplements, it provides cash transfers to families in exchange for regular school attendance and visits to health posts. The payments are provided directly to mothers or the female head of households. The other major innovation of the programme is the creation of an evaluation sample through a randomization of villages into treatment and control groups, given the impossibility to start the provision of benefits everywhere simultaneously. 
The ENCEL looks at households and their communities with great detail. For households, it provides information on expenditure and income levels, labour market participation and socio-demographic characteristics, asset ownership and family wealth, and even information on private transfers, including remittances between conationals. At the community level, it includes the socio-economic characteristics of localities, such as their access and distance to physical, health and educational public infrastructure. Furthermore, one can find information on health and weather related shocks and their impacts, both at the household and community levels. This level of comprehensiveness along with the fact that the same group of households are tracked over time make the ENCEL especially attractive for studying patterns of vulnerability in these communities.

It was also decided to obtain and process a detailed account of rainfall records expressed on a monthly basis for a period of 40 years (from 1961 through 2000) coming from meteorological stations spread across the localities under study. We make use of the full rainfall distribution obtained to instrument our main variable of interest (i.e., vulnerability to poverty) as the proneness to future poverty might present a reciprocal causation with transfers. This is explained in full detail in Section 4.

Despite its ample coverage of many topics, the ENCEL did not apply the same questions in each round of the survey. Each contains a common group of enquiries on the demographic composition of households and their socio-economic status, but many other questions were replaced by round-specific modules designed to capture other aspects of interest to policymakers. As a result, most of the seven waves of the household questionnaires have a core set of identical questions and a series of modules on different topics. This situation restricts comparison across rounds. In the end, the main data source for this paper will be three rounds of the ENCEL spaced one year apart (i.e., October 1998, November 1999 and November 2000) that contain detailed modules on private transfers.

\subsection{Transfers}

Each of the three rounds in the ENCEL contains data on different types of interhousehold transfers in two separate sections. The first asks if the household has received and/or given any type of support (cash, food, clothing, or work) in the last month, from and/or to relatives, friends or neighbours. A second section is devoted exclusively to permanent migrants. It enquires about any form of support received, but over the last six months, and only from those who had lived with the family and left within the five years prior to the survey date. In both sections, only cash transfers are given a monetary value. Likewise, both sections contain information on some characteristics of donors, including whether they live inside or outside the country.

It should be said at this stage that we treat foreign remittances as part of the system of private transfers that prevails in these communities and therefore the analysis encompasses them unless it is stated otherwise. The place of origin of the transfer should not make any difference to our microlevel analysis of incidence because any possible distance factor hindering remittances has been blurred by the progressive access to wire transfer technologies by migrants in the US and the fact that their reception at the rural village could be in pesos. However, we do distinguish foreign remittances when considering the relevance that the levels of transfers have on future 
poverty given that foreign migrants send more money on average than their domestic counterparts.

Table 1 Incidence and levels of private transfers

\begin{tabular}{|c|c|c|c|c|c|c|c|c|c|}
\hline & \multicolumn{3}{|c|}{ October 1998} & \multicolumn{3}{|c|}{ November 1999} & \multicolumn{3}{|c|}{ November 2000} \\
\hline & Total & $\mathrm{T}$ & $\mathrm{C}$ & Total & $\mathrm{T}$ & $\mathrm{C}$ & Total & $\mathrm{T}$ & C \\
\hline No. of observations & 18892 & 11389 & 7503 & 18893 & 11388 & 7505 & 18888 & 11385 & 7503 \\
\hline \multicolumn{10}{|l|}{$\%$ households that } \\
\hline Received transfer from anyone & 10.62 & 10.47 & 10.9 & 8.63 & 8.45 & 8.9 & 7.88 & 7.95 & 7.78 \\
\hline - from family & 9.96 & 9.86 & 10.1 & 7.99 & 7.78 & 8.31 & 7.15 & 7.33 & 6.89 \\
\hline - from friends & 0.59 & 0.55 & 0.65 & 0.56 & 0.58 & 0.53 & 0.74 & 0.58 & 0.97 \\
\hline - gave transfer to anyone & 0.79 & 0.75 & 0.85 & 0.16 & 0.13 & 0.2 & 0.26 & 0.29 & 0.21 \\
\hline \multicolumn{10}{|c|}{$\%$ of households that gave or received } \\
\hline - any type of transfer & 11.22 & 11.04 & 11.5 & 8.77 & 8.57 & 9.07 & 8.08 & 8.15 & 7.97 \\
\hline - monetary transfer & 8.78 & 8.66 & 8.96 & 6.6 & 6.55 & 6.68 & 6.63 & 6.75 & 6.45 \\
\hline - non-monetary transfer & 3.06 & 2.99 & 3.18 & 2.57 & 2.37 & 2.87 & 1.68 & 1.62 & 1.79 \\
\hline \multicolumn{10}{|c|}{$\%$ of households that received from abroad } \\
\hline - any type of transfer & 2.57 & 2.54 & 2.62 & 2.13 & 1.99 & 2.35 & 2.81 & 2.82 & 2.8 \\
\hline - monetary transfer & 2.52 & 2.49 & 2.55 & 2.05 & 1.94 & 2.21 & 2.71 & 2.71 & 2.71 \\
\hline - non-monetary transfer & 0.14 & 0.14 & 0.13 & 0.16 & 0.11 & 0.24 & 0.15 & 0.16 & 0.13 \\
\hline \multirow[t]{3}{*}{ - gave transfer to anyone abroad } & 0 & 0 & 0 & 0 & 0 & 0 & 0.02 & 0.02 & 0 \\
\hline & \multicolumn{3}{|c|}{ October 1998} & \multicolumn{3}{|c|}{ November 1999} & \multicolumn{3}{|c|}{ November 2000} \\
\hline & Total & $\mathrm{T}$ & C & Total & $\mathrm{T}$ & $\mathrm{C}$ & Total & $\mathrm{T}$ & $\mathrm{C}$ \\
\hline No. of observations & 18892 & 11389 & 7503 & 18893 & 11388 & 7505 & 18888 & 11385 & 7503 \\
\hline \multicolumn{10}{|c|}{ Transfers received (as \% of average consumption) } \\
\hline Over all households ${ }^{1}$ & 2.92 & 4.75 & 7.37 & 3.06 & 4.88 & 8.03 & 3.95 & 6.52 & 10.15 \\
\hline Conditional on transfers ${ }^{2}$ & 34.27 & 31.84 & 37.93 & 50.88 & 47.04 & 57.01 & 62.41 & 58.46 & 68.76 \\
\hline \multicolumn{10}{|c|}{ Transfers from abroad (as \% of average consumption) } \\
\hline Over all households ${ }^{2}$ & 1.60 & 2.61 & 4.12 & 1.86 & 2.97 & 4.93 & 2.26 & 3.63 & 5.65 \\
\hline Conditional on transfers ${ }^{3}$ & 61.38 & 58.65 & 65.60 & 92.78 & 83.67 & 106.46 & 84.07 & 80.99 & 88.97 \\
\hline
\end{tabular}

Notes: $\quad{ }^{1}$ All changes significant at 1\%, except between Oct. 1998 and Nov. 2000.

${ }^{2}$ All changes significant at 1\%, except between Oct. 1998 and Nov. 1999.

${ }^{3}$ Only change significant at $1 \%$ is between Oct. 1998 and Nov. 2000.

$\mathrm{T}=$ treatment $\mathrm{C}=$ control

For the construction of the private transfer variables, we aggregated all individual information into the household. Since any transfer comprises both its activation and the actual level mobilized, we first created a dummy that takes a value of one if any monetary or non-monetary transfer had been received. Second, we calculated the net level of transfers exchanged. This is almost equivalent to the amount of transfers received, as the percentage of households giving support back is negligible. To 
construct this variable we summed the information regarding inward and outward transfers given by or to outsiders over the previous month, adjusting the permanent migrant's remittances to a monthly basis for comparability. Some double counting of transfers is possible since those permanent migrants who provided a transfer could be the same relatives that reported giving away in the last month. The transfer levels variable was thus constructed as an aggregate of the two sections referred to above, netting out double counting as others have done previously (Teruel and Davis, 2000).

Overall, the proportion of families receiving transfers or, more generally, reporting transactions, gradually drops over the course of the three years. This could have been caused by a response bias originated by respondents in the treatment groups that were afraid that they would stop receiving benefits, or no longer qualify for them in the case of control groups which led to underreporting. The amounts transferred followed the reverse trend, with their incidence increasing every year as shown in Table 1.

\subsubsection{Going to the neediest?}

As initially stated, we were tempted to consider the existence of national and transnational support networks as something common and widespread in these villages given that agricultural activities in poor rural areas are more vulnerable to shocks and formal institutions for risk management less developed. However, if the rates of transfers exchanged between households were indicative of the support networks available in these communities, these would be surprisingly low. As Table 1 illustrates, only about one in every ten households reported giving or receiving any type of transfer during October 1998 and this decreased in the following two years. This low figure could be a consequence of the questionnaire design, as the report period for transfers from friends, neighbours and relatives considers only one month prior to the survey. However, it could also mean that even if poor households usually get involved in networks, their low resource bases or other factors not visible to us make support unlikely. In addition, most of the exchanges reported by friends, neighbours and relatives are one way transactions with less than one per cent of households giving any type of transfer in October 1998 and an even smaller proportion in the following two years. This adds to our suspicion that transfers do not always reach those in most need, as there seems to be a negligible flow of resources from better to worse off households within the same locality.

From the household's welfare point of view, it also seems that transfers are not going to the poorest members in these communities. Table 2 disaggregates our vulnerability estimates by quartiles to show that those facing the least threat of future poverty (lower quartiles) are better endowed, and receive more and higher levels of transfers. In both years, for instance, the share of households receiving foreign remittances in the first quartile is more than four times those in the top quartile. The same trend is reproduced for transfers overall. In November 1999, almost one fifth of the least vulnerable households received grants, while that proportion reached only five per cent among the more vulnerable (highest quartile). Similarly, in November 2000, the share of households receiving transfers in the lowest quartile is more than three times those in the fourth quartile. 
Table 2 Vulnerability to poverty by quartiles

\begin{tabular}{lccccccccc}
\hline & \multicolumn{3}{c}{ VTP November 1999 } & \multicolumn{5}{c}{ VTP November 2000 } \\
\hline & 1 & 2 & 3 & 4 & 1 & 2 & 3 & 4 \\
Consumption per capita \$ & 327.22 & 225.85 & 176.98 & 136.47 & 323.55 & 227.49 & 178.03 & 138.44 \\
Household size \# & 2.98 & 4.37 & 5.69 & 7.58 & 3.16 & 4.36 & 5.63 & 7.47 \\
Dependency ratio \% & 0.70 & 0.91 & 1.19 & 1.46 & 0.71 & 0.91 & 1.18 & 1.46 \\
Female head \% & 0.21 & 0.12 & 0.08 & 0.05 & 0.20 & 0.12 & 0.08 & 0.06 \\
Head is widow \% & 0.21 & 0.11 & 0.07 & 0.05 & 0.20 & 0.11 & 0.07 & 0.05 \\
Head is wage labourer \% & 0.48 & 0.56 & 0.60 & 0.61 & 0.48 & 0.56 & 0.60 & 0.61 \\
Working members at home \% & 0.41 & 0.33 & 0.28 & 0.24 & 0.41 & 0.33 & 0.28 & 0.24 \\
Asset index & 0.29 & 0.27 & 0.24 & 0.20 & 0.30 & 0.26 & 0.23 & 0.19 \\
Cattle \# & 0.93 & 0.66 & 0.55 & 0.48 & 1.04 & 0.60 & 0.55 & 0.44 \\
Avg. schooling of household migrants \# & 8.98 & 9.28 & 9.21 & 9.14 & 9.17 & 9.21 & 9.11 & 9.08 \\
Has received a transfer \% & 0.17 & 0.08 & 0.06 & 0.05 & 0.16 & 0.09 & 0.06 & 0.05 \\
Has received domestic transfer \% & 0.12 & 0.06 & 0.04 & 0.04 & 0.11 & 0.07 & 0.04 & 0.04 \\
Has received foreign transfer \% & 0.05 & 0.02 & 0.02 & 0.01 & 0.05 & 0.02 & 0.02 & 0.01 \\
Net level of transfer \$ & 65.72 & 26.79 & 19.16 & 16.89 & 65.67 & 28.17 & 19.14 & 15.59 \\
Net level of domestic transfer \$ & 30.96 & 10.38 & 6.66 & 5.98 & 29.77 & 12.25 & 5.98 & 5.97 \\
Net level of foreign transfer \$ & 34.29 & 16.24 & 12.20 & 10.78 & 35.46 & 15.57 & 13.13 & 9.35 \\
\hline Note: $\quad$ All monetary amounts expressed in August 1998 & pesos $\$$ (\$). & & & &
\end{tabular}

\subsubsection{Where do transfers go and where do they come from?}

In Table 3 we observe that transfers regardless of their place of origin tend to go to smaller households with fewer children and more elders and to families with few working adult members but more permanent migrants. Widow female headed households are one of the main groups reached by private transfers.

On the other hand, having a permanent migrant seems to have great relevance for recipient families. By far the main contingent that leave home are the offspring. As Tables 4 and 5 prove, most of them domestically and internationally leave unmarried and for working purposes, especially the later group. Migrating daughters stay closer to their homes than sons, who more often migrate to the United States. Finally, male foreign migrants are more likely to provide support than females, and this is done mostly in cash, and in higher amounts. In the case of international remittances there is also a gradual increase in the amount of remittances sent back home, which corresponds with the national trends observed between 1998 and 2000. 
Table 3 Household characteristics by receipt of transfers

\begin{tabular}{|c|c|c|c|c|c|c|}
\hline & \multicolumn{2}{|c|}{ October 1998} & \multicolumn{2}{|c|}{ November 1999} & \multicolumn{2}{|c|}{ November 2000} \\
\hline & & Not & & Not & & Not \\
\hline \multirow[t]{2}{*}{ Variable } & Received & Received & Received & Received & Received & Received \\
\hline & \multicolumn{6}{|c|}{ DOMESTIC } \\
\hline Consumption per capita $\$$ & 304.79 & 226.96 & 242.00 & 197.90 & 271.21 & 207.71 \\
\hline Household size \# & 3.99 & 5.55 & 4.05 & 5.45 & 3.52 & 5.16 \\
\hline Children 0-5 \# & 0.53 & 1.03 & 0.42 & 0.81 & 0.89 & 1.17 \\
\hline Male 6-14 \# & 0.54 & 0.78 & 0.56 & 0.75 & 0.51 & 0.77 \\
\hline Female 6-14 \# & 0.49 & 0.76 & 0.52 & 0.72 & 0.51 & 0.75 \\
\hline Male 15-64 \# & 1.12 & 1.52 & 0.94 & 1.43 & 1.13 & 1.60 \\
\hline Female 15-64 \# & 1.26 & 1.52 & 1.08 & 1.44 & 1.27 & 1.61 \\
\hline Male $>65 \#$ & 0.28 & 0.14 & 0.23 & 0.15 & 0.35 & 0.17 \\
\hline Female $>65 \#$ & 0.32 & 0.13 & 0.30 & 0.14 & 0.40 & 0.15 \\
\hline Head age \# & 64.54 & 49.74 & 64.92 & 51.41 & 69.07 & 52.48 \\
\hline Head female \% & 0.39 & 0.13 & 0.39 & 0.15 & 0.42 & 0.17 \\
\hline Head is widow \% & 0.39 & 0.14 & 0.44 & 0.17 & 0.50 & 0.17 \\
\hline Head is agricultural labourer \% & 0.34 & 0.59 & 0.35 & 0.57 & 0.24 & 0.54 \\
\hline Head in non-agriculture \% & 0.04 & 0.07 & 0.04 & 0.08 & 0.03 & 0.08 \\
\hline Working members at home $\%$ & 0.30 & 0.32 & 0.26 & 0.32 & 0.22 & 0.31 \\
\hline Asset index & 0.21 & 0.21 & 0.15 & 0.25 & 0.24 & 0.26 \\
\hline \multirow[t]{2}{*}{ Household has a migrant $\%$} & 0.58 & 0.13 & 0.56 & 0.14 & 0.43 & 0.12 \\
\hline & \multicolumn{6}{|c|}{ FOREIGN } \\
\hline Consumption per capita $\$$ & 329.83 & 230.77 & 325.29 & 198.08 & 331.17 & 207.54 \\
\hline Household size \# & 4.74 & 5.44 & 4.28 & 5.38 & 4.55 & 5.09 \\
\hline Children 0-5 \# & 0.58 & 1.00 & 0.41 & 0.79 & 1.23 & 1.15 \\
\hline Male 6-14 \# & 0.66 & 0.77 & 0.54 & 0.75 & 0.67 & 0.76 \\
\hline Female 6-14 \# & 0.65 & 0.74 & 0.54 & 0.71 & 0.62 & 0.74 \\
\hline Male 15-64 \# & 1.35 & 1.50 & 0.89 & 1.41 & 1.76 & 1.57 \\
\hline Female 15-64 \# & 1.52 & 1.50 & 1.41 & 1.42 & 1.84 & 1.58 \\
\hline Male $>65 \#$ & 0.27 & 0.15 & 0.27 & 0.15 & 0.23 & 0.18 \\
\hline Female $>65 \#$ & 0.24 & 0.14 & 0.23 & 0.14 & 0.21 & 0.17 \\
\hline Head age \# & 61.43 & 51.23 & 64.26 & 52.40 & 58.11 & 53.79 \\
\hline Head female \% & 0.26 & 0.16 & 0.28 & 0.18 & 0.33 & 0.19 \\
\hline Head is widow \% & 0.30 & 0.17 & 0.38 & 0.19 & 0.32 & 0.20 \\
\hline Head is agricultural labourer \% & 0.33 & 0.57 & 0.27 & 0.56 & 0.22 & 0.53 \\
\hline Head in non-agriculture \% & 0.08 & 0.07 & 0.05 & 0.07 & 0.03 & 0.08 \\
\hline Working members at home $\%$ & 0.31 & 0.32 & 0.23 & 0.31 & 0.23 & 0.31 \\
\hline Asset index & 0.39 & 0.21 & 0.44 & 0.23 & 0.49 & 0.25 \\
\hline Household has a migrant $\%$ & 0.73 & 0.15 & 0.69 & 0.16 & 0.81 & 0.12 \\
\hline
\end{tabular}

Note. Monetary amounts expressed in August 1998 pesos (\$). 
Table 4 Characteristics of domestic permanent migrants

\begin{tabular}{|c|c|c|c|c|c|c|c|c|c|}
\hline \multirow[b]{2}{*}{ Variable } & \multicolumn{3}{|c|}{ October 1998} & \multicolumn{3}{|c|}{ October 1999} & \multicolumn{3}{|c|}{ November 2000} \\
\hline & Total & Male & Female & Total & Male & Female & Total & Male & Female \\
\hline $\begin{array}{l}\text { Households w/domestic migrants \% } \\
\text { (over those w/permanent migrants) }\end{array}$ & 81.47 & & & 77.45 & & & 70.56 & & \\
\hline $\begin{array}{l}\text { Households w/domestic migrants \% } \\
\text { (over all households) }\end{array}$ & 13.26 & & & 13.09 & & & 9.88 & & \\
\hline Domestic migrants \# & 4566 & 2191 & 2375 & 4784 & 2210 & 2574 & 4140 & 1953 & 2187 \\
\hline Civil status at departure Obs. & 4297 & 2060 & 2237 & 4234 & 1945 & 2289 & 3984 & 1882 & 2102 \\
\hline Unmarried \% & 74.5 & 71.6 & 72.3 & 67.8 & 67.8 & 67.8 & 66.4 & 66.4 & 66.8 \\
\hline Married & 15.9 & 18.7 & 13.2 & 17.5 & 18.2 & 16.9 & 29.4 & 23.4 & 22.2 \\
\hline Cohabitation & 6.5 & 7.7 & 5.5 & 10.6 & 11.4 & 9.9 & 6.6 & 7.3 & 6.0 \\
\hline Separated & 1.6 & 1.3 & 1.9 & 2.2 & 1.4 & 2.9 & 1.6 & 1.1 & 2.2 \\
\hline Widowed & 1.2 & 0.6 & 1.8 & 1.8 & 1.2 & 2.3 & 2.2 & 1.7 & 2.6 \\
\hline Kinship with head Obs. & 4404 & 2109 & 2295 & 4699 & 2167 & 2532 & 4115 & 1935 & 2180 \\
\hline Son/daughter \% & 88.0 & 88.9 & 87.3 & 72.1 & 73.2 & 71.2 & 64.2 & 67.3 & 61.3 \\
\hline Husband/wife or partner & 0.9 & 1.5 & 0.3 & 1.3 & 2.0 & 0.8 & 2.2 & 3.1 & 1.4 \\
\hline Brother/sister & 1.6 & 1.8 & 1.5 & 2.6 & 3.8 & 2.2 & 3.8 & 4.1 & 3.4 \\
\hline Son/daughter-in-law & 2.1 & 0.9 & 3.2 & 5.8 & 2.5 & 8.6 & 6.5 & 2.4 & 10.1 \\
\hline Niece & 3.9 & 3.9 & 3.9 & 10.9 & 11.5 & 10.3 & 11.0 & 10.7 & 11.3 \\
\hline Nephew & 0.9 & 1.0 & 0.7 & 2.2 & 2.5 & 2.0 & 2.9 & 3.0 & 2.9 \\
\hline Reason for leaving home Obs. & 4533 & 2169 & 2364 & 4740 & 2189 & 2551 & 4020 & 1893 & 2127 \\
\hline Work \% & 46.2 & 55.6 & 37.5 & 37.2 & 43.7 & 31.7 & 37.7 & 47.5 & 29.0 \\
\hline Got married & 32.9 & 23.9 & 41.1 & 27.9 & 20.6 & 34.1 & 25.0 & 15.9 & 33.1 \\
\hline Study & 6.2 & 6.3 & 6.1 & 5.3 & 5.6 & 5.0 & 2.7 & 3.1 & 2.4 \\
\hline Problems & 2.5 & 2.5 & 2.5 & 3.1 & 3.1 & 3.1 & 3.5 & 3.7 & 3.4 \\
\hline Other & 12.33 & 11.8 & 12.8 & 26.6 & 27.1 & 26.2 & 31.0 & 29.8 & 32.0 \\
\hline Type of support Obs. & 4322 & 2073 & 2249 & 4265 & 1956 & 2309 & 4124 & 1944 & 2180 \\
\hline No support provided \% & 73.2 & 68.9 & 77.1 & 86.7 & 83.7 & 89.1 & 88.5 & 86.4 & 90.4 \\
\hline Cash & 22.2 & 26.5 & 18.3 & 12.5 & 15.2 & 10.3 & 9.1 & 11.4 & 7.1 \\
\hline In kind & 3.6 & 3.6 & 3.4 & 0.6 & 0.6 & 0.6 & 2.0 & 1.8 & 2.3 \\
\hline Transfer Obs. & 937 & 403 & 534 & 522 & 286 & 236 & 374 & 220 & 154 \\
\hline (over those persons that sent) $\$$ & 572 & 535 & 600 & 1013 & 1100 & 908 & 1119 & 1247 & 935 \\
\hline Transfer Obs. & 4562 & 2188 & 2374 & 4769 & 2203 & 2566 & 4113 & 1944 & 2169 \\
\hline (over all domestic migrants) \$ & 117 & 146 & 91 & 111 & 142 & 83 & 101 & 140 & 66 \\
\hline
\end{tabular}


Table 5 Characteristics of permanent migrants abroad

\begin{tabular}{|c|c|c|c|c|c|c|c|c|c|}
\hline \multirow[b]{2}{*}{ Variable } & \multicolumn{3}{|c|}{ October 1998} & \multicolumn{3}{|c|}{ October 1999} & \multicolumn{3}{|c|}{ November 2000} \\
\hline & Total & Male & Female & Total & Male & Female & Total & Male & Female \\
\hline $\begin{array}{l}\text { Households w/domestic migrants \% } \\
\text { (over those w/permanent migrants) }\end{array}$ & 16.48 & & & 15.69 & & & 25.83 & & \\
\hline $\begin{array}{l}\text { Households w/domestic migrants \% } \\
\text { (over all households) }\end{array}$ & 2.68 & & & 2.65 & & & 3.61 & & \\
\hline Migrants abroad \# & 749 & 563 & 186 & 747 & 555 & 192 & 1027 & 774 & 253 \\
\hline Residence (all migrants) Obs. & 5315 & 2754 & 2561 & 6092 & 3020 & 3072 & 5167 & 2727 & 2440 \\
\hline Same locality & 22.7 & 21.3 & 24.2 & 19.9 & 18.8 & 20.9 & 27.8 & 23.9 & 32.2 \\
\hline Nearby locality & 7.1 & 4.0 & 10.5 & 8.0 & 5.9 & 10.3 & 6.2 & 4.4 & 8.1 \\
\hline Same municipality & 5.1 & 3.4 & 6.9 & 5.3 & 3.8 & 6.7 & 4.4 & 3.1 & 5.8 \\
\hline Same state & 13.9 & 11.6 & 16.3 & 14.0 & 11.5 & 15.7 & 11.7 & 10.7 & 12.8 \\
\hline Another state & 36.2 & 38.2 & 33.9 & 31.7 & 33.2 & 30.2 & 30.1 & 29.5 & 30.7 \\
\hline Another country & 14.1 & 20.4 & 7.3 & 12.0 & 18.4 & 6.3 & 19.9 & 28.4 & 10.4 \\
\hline Civil status at departure Obs. & 738 & 553 & 184 & 720 & 539 & 181 & 1017 & 767 & 250 \\
\hline Unmarried \% & 80.5 & 82.3 & 75.0 & 72.1 & 72.0 & 72.4 & 71.6 & 71.8 & 70.8 \\
\hline Married & 13.7 & 12.3 & 17.9 & 21.3 & 21.9 & 19.3 & 22.8 & 23.2 & 21.6 \\
\hline Cohabitation & 3.0 & 3.1 & 2.7 & 3.8 & 3.7 & 3.9 & 3.9 & 3.7 & 4.8 \\
\hline Separated & 1.4 & 1.3 & 1.6 & 2.1 & 1.9 & 2.8 & 0.8 & 0.5 & 1.6 \\
\hline Widowed & 1.5 & 1.1 & 2.7 & 0.8 & 0.6 & 1.7 & 0.8 & 0.8 & 0.8 \\
\hline Kinship with head Obs. & 726 & 541 & 185 & 721 & 533 & 188 & 1022 & 769 & 253 \\
\hline Son/daughter \% & 92.2 & 91.7 & 93.5 & 86.6 & 86.7 & 86.2 & 75.0 & 76.7 & 69.6 \\
\hline Husband/wife or partner & 2.9 & 3.7 & 0.5 & 4.6 & 5.6 & 1.6 & 10.4 & 13.5 & 0.8 \\
\hline Brother/Sister & 1.5 & 1.9 & 0.5 & 0.6 & 0.8 & 0.0 & 1.2 & 0.8 & 2.4 \\
\hline Son/daughter-in-law & 1.1 & 0.7 & 2.2 & 2.5 & 1.5 & 0.0 & 3.7 & 1.4 & 10.7 \\
\hline Niece & 1.0 & 0.9 & 1.1 & 2.8 & 3.0 & 5.3 & 6.2 & 4.7 & 10.7 \\
\hline Nephew & 0.6 & 0.7 & 0.0 & 0.8 & 0.9 & 2.1 & 0.7 & 0.5 & 1.2 \\
\hline Reason for leaving home Obs. & 747 & 562 & 185 & 744 & 554 & 190 & 1014 & 764 & 250 \\
\hline Work \% & 81.8 & 88.8 & 60.5 & 82.3 & 89.7 & 60.5 & 79.5 & 88.4 & 52.4 \\
\hline Got married & 13.8 & 6.8 & 35.1 & 9.5 & 4.2 & 25.3 & 9.1 & 3.4 & 26.4 \\
\hline Study & 2.3 & 2.3 & 2.2 & 2.4 & 1.8 & 4.2 & 2.4 & 2.8 & 1.2 \\
\hline Problems & 0.5 & 0.5 & 0.5 & 0.3 & 0.4 & 0.0 & 0.4 & 0.5 & 0.0 \\
\hline Other & 1.6 & 1.6 & 1.6 & 5.5 & 4.0 & 10.0 & 8.7 & 5.0 & 20.0 \\
\hline Type of support Obs. & 738 & 553 & 185 & 723 & 540 & 183 & 1016 & 764 & 252 \\
\hline No support provided \% & 45.5 & 40.3 & 61.1 & 57.4 & 53.7 & 68.3 & 53.4 & 45.7 & 77.0 \\
\hline Cash & 53.4 & 59.0 & 36.8 & 42.3 & 46.3 & 30.6 & 44.4 & 52.2 & 20.6 \\
\hline In kind & 0.3 & 0.2 & 0.5 & 0.0 & 0.0 & 0.0 & 2.0 & 2.0 & 2.0 \\
\hline Transfer Obs. & 391 & 324 & 67 & 303 & 248 & 55 & 437 & 387 & 50 \\
\hline (over those persons that sent) $\$$ & 1892 & 1973 & 1499 & 3924 & 3637 & 5216 & 4085 & 4217 & 3058 \\
\hline Transfer Obs. & 749 & 563 & 186 & 742 & 551 & 191 & 1027 & 774 & 253 \\
\hline (over all migrants abroad) & 998 & 1136 & 540 & 1592 & 1625 & 1494 & 1738 & 2109 & 604 \\
\hline
\end{tabular}




\section{Econometric estimation}

The relationship between an increase in the risk of future poverty (VTP) for households and their prospects for receiving support from others will be addressed formally by adopting the following specification

$$
\mathrm{T}_{\mathrm{h}, \mathrm{t}}=\mathrm{a}+\mathrm{bX} \mathrm{h}, \mathrm{t}_{\mathrm{t}}+\mathrm{b}_{2} \mathrm{R}_{\mathrm{h}, \mathrm{t}}+\mathrm{b}_{3}(\mathrm{VTP})_{\mathrm{h}, \mathrm{t}+1}+\mathrm{e}_{\mathrm{h}, \mathrm{t}}
$$

where $\mathrm{T}$ is a latent variable that results from an unobserved continuous process that determines the propensity to receive transfers and takes positive values if the transfer is received. In (3) if $\mathrm{T}>0$ then the transfers received take a value of one whereas if $\mathrm{T}<=0$, the transfers observed take the value of zero. $\mathrm{X}$ is a vector of household controls that could affect the incidence and level of grants obtained. We contemplate several features of the household head; the ratio between dependent and working age members, the percentage of working household members and if the household reported to have any permanent migrants; some asset endowments such as land hectares possessed and cattle units; and finally, public transfers from different government programs. ${ }^{7} \mathrm{R}$ is a vector of dummies that contains multiple impacts from weather related shocks (i.e., destruction or loss of physical and human capital in the form of land, crops, animals, items or home, or if any member from the family died, got injured or migrated to look for more promising economic opportunities elsewhere) and health shocks (i.e., the number of productive days lost by the breadwinner due to illness) as well as the number of sick children reported by households. As usual, the error term e is assumed to be normally distributed. Our main regressor is the vulnerability score to future consumption poverty of each household (VTP). On a purely normative ground, if our coefficient of interest $b_{3}$ turns out positive $\left(b_{3}>0\right)$, it would indicate that the need for mutual insurance which an increase in vulnerability would require would be compensated for by a higher probability of receiving transfers. Given our current dataset, this specification translates into a model of the incidence of transfers for those already poor in October 1998 given the possibility of staying poor or becoming poor(er) in November 1999, as well as the incidence for November 1999 given the likelihood of staying poor or becoming poor(er) a year after.

However, such a specification could pose endogeneity problems between the dependent variable and our main regressor VTP. By definition, the future welfare outcome used for the computation of vulnerability takes into account both negative and positive shocks, including public and private transfers. It would therefore be difficult to detect what effect increasing the risk of future poverty could have on receiving more private transfers.

The proposed solution is to obtain the relevant parameters through an Instrumental Maximum Likelihood Estimation Probit model on the probability of receiving a transfer. We circumvent the problem of endogeneity through the identification of proper instruments for VTP that would purge its correlation with the residual $e_{h}$. The

7 Table 2 shows that the average years of education for migrant household members across vulnerability quartiles are similar. We find no reason to control for this poverty trap effect in which remittances to more vulnerable families could be lower due to the fact that more vulnerable families were poorer in the usual sense and that both poorer families and their migrant members had lower levels of human and social capital (so their migrant members earned less and hence had less to remit). 
endogenous variable VTP would be regressed upon such set of instruments and fit into the full Probit model; in other words, once instrumented VTP will be used as an explanatory variable in the private transfer equation to compute the relevant parameters.

The selected instruments consist of the standard deviation of the aforementioned absolute rainfall distribution as well as the bottom 20th percentile of the same rainfall distribution alone and interacted with the amount of cattle and land possessed by the household and the percentage of working members at home. The measures of central tendency and dispersion derived from the absolute rainfall distribution could inform about the dispersion of future consumption provided shocks materialize. Rainfall related events, for example a drought, would lead to fluctuations away from the mean given their high level of aggregation, as well as the relatively extended lack of insurance against them in rural areas. Moreover, it would be hardly credible that precipitation levels hold a contemporary correlation with the likelihood of receiving any form of private transfer making them a completely exogenous event. On the other hand, the cattle and land household controls are particularly sensitive to weather related shocks and the labour force potentially helpful to cope with them. All three are included because they can reveal part of the more stable component of the future welfare outcome employed (i.e., future consumption). Overall, this group of variables should inform us about the distribution of vulnerability. More importantly, after some testing reported in the following section we are able to confirm that they fulfil the conditions that make for a good instrument, that is, they are correlated with the endogenous regressor and uncorrelated with the residuals from equation (3) (Deaton, 1997).

Given that a transfer indeed occurs, we next consider if the amount received by the household increases or decreases given a rise in the possibility of it becoming poorer in the future. This involves a model specification where the latent variable $T$ still takes discrete choice values of zero for those unobserved remittances, but positive values for those households that actually receive remittances, making $t>=0 . X$ and $R$ are the same control vectors as before, and $\mathrm{v}$ is the truncated distribution of residuals.

$$
\mathrm{t}_{\mathrm{h}, \mathrm{t}}=\mathrm{a}+\mathrm{bX} \mathrm{h}, \mathrm{t}_{\mathrm{t}}+\mathrm{b}_{2} \mathrm{R}_{\mathrm{h}, \mathrm{t}}+\mathrm{b}_{3}(\mathrm{VTP})_{\mathrm{h}, \mathrm{t}+\mathrm{1}}+\mathrm{E}\left[\mathrm{v}_{\mathrm{h}, \mathrm{t}} \mid \mathrm{t}_{\mathrm{h}}>0\right]
$$

We believe there are no reasons to find differentiated effects on the probability of both receiving grants as well as the amount obtained. Hence, we considered a Tobin's Probit model to be an appropriate estimation strategy to account for the potential bias that arises from the truncation of $\mathrm{t}$ at zero.

\section{Results}

Our statistical analysis suggested that the remission of money or in-kind support does not appear to end up with those who are more likely to be needy in the future. Our econometric approach also reported an inverse and significant relationship between the probability of receiving a transfer and experiencing an increase in the risk of future poverty. To arrive at this conclusion, we first carried out a Probit on the incidence of domestic and foreign transfers alike. As columns (2) and (4) in Table 6 show at the bottom (non-instrumented vulnerability to poverty in $\mathrm{t}+1$ ), there is a significant and negative association between the increase in vulnerability of the rural poor across our sample of households and the remittance of transfers to them. Given that those at the 
upper end of the distribution face a higher risk of future poverty we chose to report the marginal effects at the 75 th percentile.

To reinforce our conclusion and strengthen our econometric estimation, we accounted for possible sources of endogeneity by instrumenting the variable that could have a reciprocal causation with the outcome variable (i.e., the relationship between vulnerability to poverty and the reception of transfers). The rejection of exogeneity at 99 per cent and 95 per cent confidence levels in October 1998 and November 1999, respectively, suggested that we should proceed along these lines to try to get some consistent estimates. Columns (1) and (3) display the results of the instrumental variables regression. We confirmed that the instruments are all individually and jointly significant and behave as expected. For instance, records at the bottom tail of the rainfall distribution for our group of localities increase the magnitude of the household threat of future poverty, but fluctuations away from the average level of the absolute rainfall distribution, if positive, could reduce the vulnerability of households through more precipitation. In a similar vein, the interaction of negative fluctuations on locality precipitation with rainfall related risk-sensitive assets such as land and cattle also tends to augment such exposure. On the contrary, the possible impact on vulnerability of droughts might be attenuated by an increased labour availability at home. The results in the first row of columns (2) and (4) represent our Probit model on the incidence of transfers after correcting for endogeneity. We obtained the same result as our noninstrumented Probit displayed in the bottom row of Table 2, that is, our fundamental claim regarding the negative relationship between remittances and vulnerability to poverty in this sample of rural households remains.

Finally, in accordance with our statistical exploration, households with more dependent members - especially elder people - whose head is female, elderly, and with permanent migrants are more likely to receive transfers. In contrast, those where the head is involved in agricultural wage labour and with more working members at home are less likely to obtain inflows from others. 
Table 6 Effect of correlates on the incidence of private transfers

\begin{tabular}{|c|c|c|c|c|}
\hline \multirow[t]{4}{*}{$t=$} & \multicolumn{2}{|c|}{ October 1998} & \multicolumn{2}{|c|}{ November 1999} \\
\hline & IV & Probit & IV & Probit \\
\hline & & $(\mathrm{dF} / \mathrm{dx})$ & & $(\mathrm{dF} / \mathrm{dx})$ \\
\hline & (1) & (2) & (3) & $(4)$ \\
\hline \multirow[t]{2}{*}{ Instrumented vulnerability to poverty in $t+1$} & & -0.233 & & -0.143 \\
\hline & & $(0.021)^{\star \star \star}$ & & $(0.024)^{\star \star \star}$ \\
\hline \multirow[t]{2}{*}{ Rainfall distribution (Std dev.) } & -0.000 & & -0.000 & \\
\hline & $(0.000)$ & & $(0.000)^{\star \star \star}$ & \\
\hline \multirow[t]{2}{*}{ Rainfall distribution (20th $\mathrm{p} \%$ ) } & 0.002 & & 0.002 & \\
\hline & $(0.000)^{\star * *}$ & & $(0.000)^{\star * *}$ & \\
\hline \multirow[t]{2}{*}{ \# Land ha * rainfall 20th $\mathrm{p} \%$} & 0.000 & & 0.000 & \\
\hline & $(0.000)^{\star \star *}$ & & $(0.000)^{\star * \star}$ & \\
\hline \multirow[t]{2}{*}{ \# Cattle * rainfall 20th $\mathrm{p} \%$} & 0.000 & & 0.000 & \\
\hline & $(0.000)$ & & $(0.000)^{\star \star *}$ & \\
\hline \multirow[t]{2}{*}{ Working household members * rainfall 20th $\mathrm{p} \%$} & -0.001 & & -0.001 & \\
\hline & $(0.000)^{\star \star \star}$ & & $(0.000)^{\star \star \star}$ & \\
\hline \multirow[t]{2}{*}{ Household size } & 0.043 & 0.003 & 0.044 & 0.002 \\
\hline & $(0.000)^{\star \star *}$ & $(0.001)^{\star \star}$ & $(0.000)^{\star * \star}$ & $(0.002)$ \\
\hline \multirow[t]{2}{*}{ Dependency ratio } & 0.018 & 0.008 & 0.017 & 0.004 \\
\hline & $(0.001)^{\star \star \star}$ & $(0.001)^{\star \star *}$ & $(0.001)^{\star \star \star}$ & $(0.001)^{\star \star \star}$ \\
\hline \multirow[t]{2}{*}{$\%$ Working household members } & -0.045 & -0.049 & -0.030 & -0.059 \\
\hline & $(0.005)^{\star \star \star}$ & $(0.005)^{\star \star \star}$ & $(0.007)^{\star \star \star}$ & $(0.007)^{\star \star \star}$ \\
\hline \multirow[t]{2}{*}{ Head age } & -0.003 & 0.003 & -0.002 & 0.002 \\
\hline & $(0.000)^{\star \star \star}$ & $(0.001)^{\star \star \star}$ & $(0.000)^{\star \star \star}$ & $(0.001)^{\star * *}$ \\
\hline \multirow[t]{2}{*}{ Female head } & -0.029 & 0.007 & -0.024 & 0.007 \\
\hline & $(0.003)^{\star \star \star}$ & $(0.004)^{\star}$ & $(0.003)^{\star \star \star}$ & $(0.004)^{\star}$ \\
\hline \multirow[t]{2}{*}{ Head schooling } & -0.001 & 0.000 & -0.002 & 0.000 \\
\hline & $(0.000)^{\star \star \star}$ & $(0.000)$ & $(0.000)^{\star \star \star}$ & $(0.000)$ \\
\hline \multirow[t]{2}{*}{ Head is agricultural wage labourer } & 0.008 & -0.007 & 0.019 & -0.006 \\
\hline & $(0.002)^{\star \star \star *}$ & $(0.002)^{\star * \star}$ & $(0.002)^{\star \star *}$ & $(0.003)^{\star *}$ \\
\hline \multirow[t]{2}{*}{ Head works in non-agricultural activity } & -0.103 & -0.007 & 0.003 & -0.006 \\
\hline & $(0.003)^{\star \star \star}$ & $(0.003)^{\star \star}$ & $(0.003)$ & $(0.003)^{*}$ \\
\hline \multirow[t]{2}{*}{ Land hectares } & -0.000 & 0.000 & -0.004 & -0.001 \\
\hline & $(0.000)^{\star \star \star}$ & $(0.000)$ & $(0.000)^{\star * *}$ & $(0.000)$ \\
\hline \multirow[t]{2}{*}{ Number of cattle } & -0.001 & 0.000 & -0.002 & 0.001 \\
\hline & $(0.000)^{\star \star \star}$ & $(0.000)$ & $(0.000)^{\star * *}$ & $(0.000)$ \\
\hline \multirow[t]{2}{*}{ Household has a migrant } & -0.003 & 0.206 & 0.019 & 0.222 \\
\hline & $(0.002)$ & $(0.015)^{\star \star \star}$ & $(0.002)^{\star \star \star}$ & $(0.009)^{\star \star \star}$ \\
\hline \multirow[t]{2}{*}{ Non-instrumented vulnerability to poverty in $t+1$} & & -0.140 & & -0.075 \\
\hline & & $(0.011)^{\star \star \star}$ & & $(0.010)^{\star \star *}$ \\
\hline Observations & 15574 & 15574 & 15465 & 15465 \\
\hline
\end{tabular}


Notes: (Standard errors). " significant at 10\%; ${ }^{* *}$ significant at $5 \%$; ${ }^{* * *}$ significant at $1 \%$. Marginal Effects $(\mathrm{dF} / \mathrm{dx})$ reported at the 75th percentile. Other regressors included are whether households obtained resources from various government programmes and dummies for health and weather related shock impacts.

Non-instrumented vulnerability to poverty is the same Probit model without correcting for endogeneity. The rest of the marginal effects for this Probit are not reported in the table.

The OLS and Tobit estimates on transfer levels convey the same conclusion: an increase in the risk of future poverty translates into a reduction in the level of transfers received (detailed results are available upon request). As Figure 3 illustrates this is clearly driven by foreign remittances. The negative trends of fitted values for foreign remittances (made in October 1998 and November 1999) for the instrumented index of vulnerability to poverty (for November 1999 and 2000, respectively) were more pronounced than those of general remittances. In both years, most values are comprised between the first and third quartiles as the indices follow a slightly positively skewed normal distribution as shown in Figure 2. As households move to higher levels of risk the decline in the level of grants observed becomes steeper. A non-marginal shift from the 25 th percentile of the distribution to the 75th percentile, though unlikely, would translate into a decline of approximately $\$ 140$ pesos (US\$14) in October 1998 and $\$ 100$ pesos (US\$10) in November 1999 for remittances in general, but $\$ 900$ pesos (US\$90) and $\$ 1300$ pesos (US\$130) for foreign, respectively.

Figure 3 Fitted values after Tobit in transfer levels

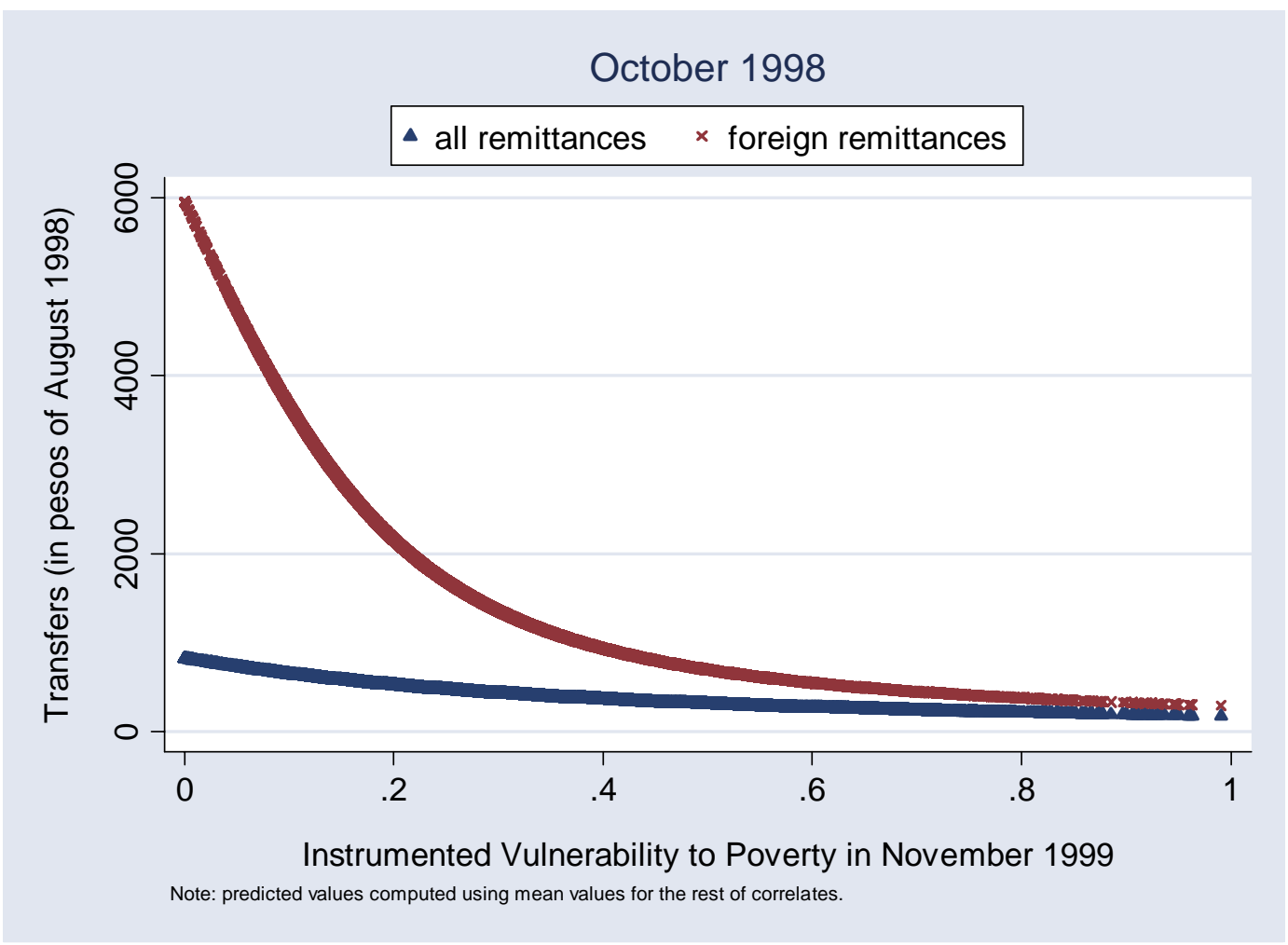




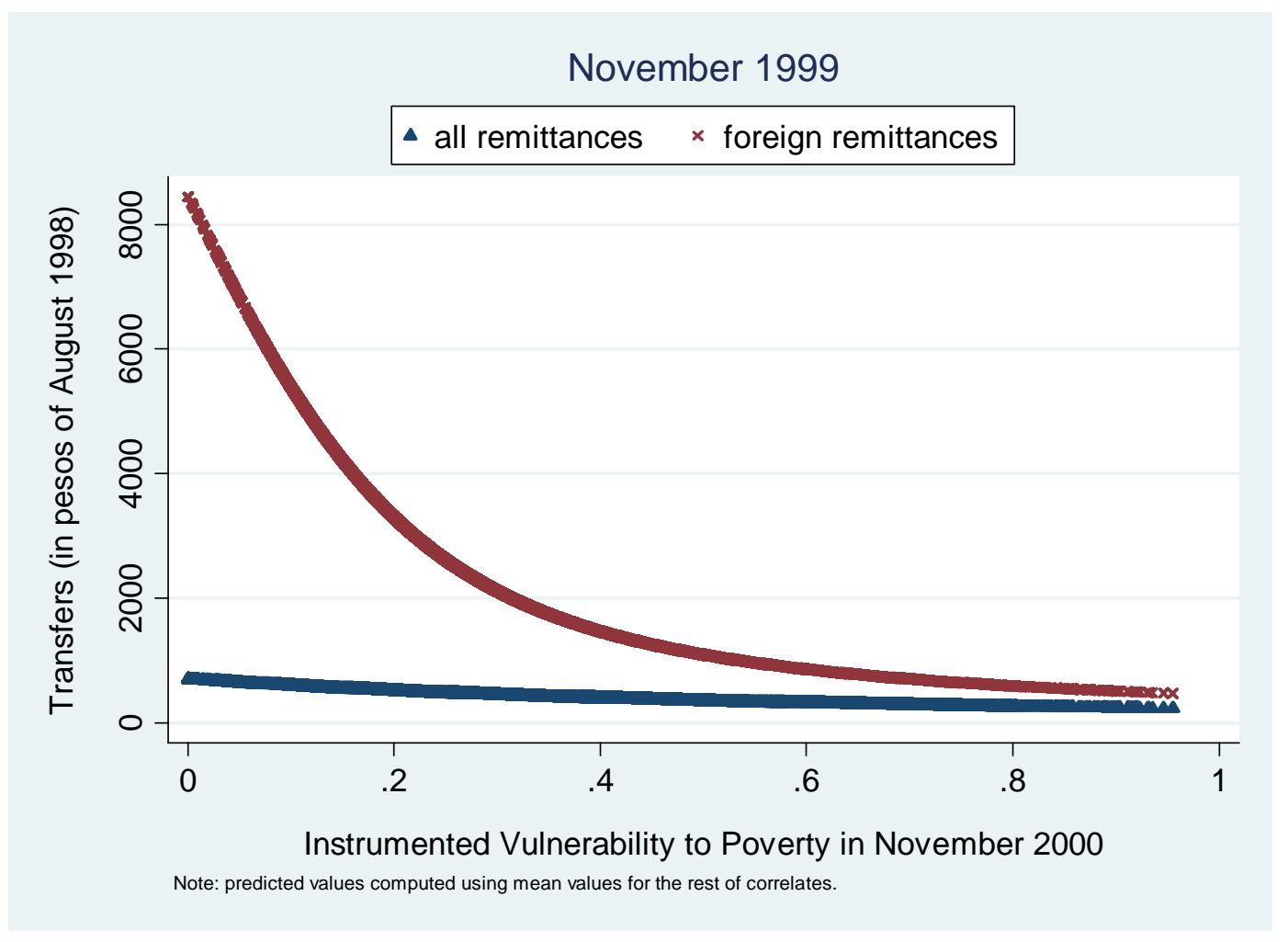

\section{Conclusion}

International remittances have been perceived as the human face of globalization especially through their potential effects on poverty as they directly increase the household's level of income and therefore should become a massive poverty reduction mechanism if targeted on deprived households. However, even though mutual support networks of relatives and friends are meant to be one of the most important resources that poor rural households can draw upon to cope with problems by providing riskpooling mechanisms in the absence or limited access to formal credit and insurance markets (Bando and López-Calva, 2004), their activation might not necessarily be aligned to the needs and risks faced by recipients.

Given that remittances have reached historically high flows in Mexico in the recent past becoming one of the most salient features that have taken place in the country under the mantra of globalization we therefore considered of most relevance to understand whether transfers, including international remittances, indeed reach those whose conditions are likely to worsen in the future.

We addressed this question by creating a model that would allow us to predict future consumption expenditures based on current household socio-demographic characteristics, as well as risk-mitigating assets. This resulted in differentiated levels of vulnerability to poverty for a panel of rural households in Mexico that extends from October 1998 to November 2000. After coming up with such levels for each household, we brought into a series of Probit and Tobit models to discern if an increase in the risk of future consumption poverty automatically translated into a higher probability for receiving help from others, including those living abroad. Caution was paid to 
reciprocal causation by instrumenting through monthly rainfall data the possible source of endogeneity contained in our vulnerability regressor.

We found with statistical significance that an increase in the threat to future poverty that rural families could experience reduces their likelihood of receiving transfers, including foreign remittances. We did not enquire as to why this could be the case as this would demand more information about migrant households themselves which was not available, such as the migrants' earnings and other important personal characteristics. Certainly this remains a line of research worth exploring in the future. On a more speculative ground, even though pure altruistic considerations to send remittances cannot be fully discarded, a highly asymmetrical relationship seems to pervade the relationship between donors and recipients in our sample leaving the migrant with few incentives to abide by a mutual arrangement. As a result, a reduced probability for private transfers to reach households that experience an increase in the risk of future poverty could be the outcome of a highly skewed insurance arrangement where the migrant applies an exit option because it perceives no further incentives or gains for staying in it.

Facilitating foreign remittances, or more generally, private transfers, for rural recipients should not be considered a safety valve against poverty nor a substitute for the introduction of publicly funded schemes of social protection coupled with the gradual improvement of economic conditions in the home villages that could encourage young people to stay, and parents to stop making costly and high risk investments on their behalf.

\section{References}

Bando, R. and López-Calva, L. F. (2004). 'The Rural Sector and Informal Safety Nets: Evidence from Mexico'. Working Paper 02. Puebla: Universidad de las America, Institute of Public Policy and Development Studies.

Calvo, C. and Dercon, S. (2005). 'Measuring Individual Vulnerability'. Working Paper 229. Oxford: University of Oxford, Department of Economics.

Deaton, A. (1997). The Analysis of Household Surveys: A Microeconomic Approach. Baltimore: Johns Hopkins University Press.

de la Fuente, A. (2005). 'Vulnerability to Poverty in Rural Mexico'. PhD Dissertation, Oxford. University of Oxford, Department of International Development.

Fajnzylber, P. and Humberto L. J. (2007). Close to Home: The Development Impact of Remittances in Latin America. Washington, DC: World Bank.

García-Verdu, R. (2002). 'Risk-sharing in Rural Mexico'. Chicago: University of Chicago, mimeo.

Goldstein, M., de Janvry, A., and Sadoulet, E. (2004). 'Is a Friend in Need a Friend Indeed? Inclusion and Exclusion in Mutual Insurance Networks in Southern Ghana', in S. Dercon (ed.), Insurance against Poverty. Oxford: Oxford University Press for UNU-WIDER. 
Lanjouw, P. (1998). 'Poverty and the Non-Farm Economy in Mexico's Ejidos: 19941997'. Background paper prepared for Economic Adjustment and Institutional Reform: Mexico's Ejido Sector Responds. Washington, DC: World Bank.

Lucas, R. E. B. and Stark, O. (1985). 'Motivations to Remit: Evidence from Botswana'. Journal of Political Economy, 93(5): 901-18.

Orozco, M. (2002). 'Globalization and Migration: The Impact of Family Remittances in Latin America'. Latin American Politics and Society, 44(2): 41-66.

_ (2002). 'Worker Remittances: The Human Face of Globalization'. Inter-American Dialogue. Working Paper commissioned by the Multilateral Investment Fund of the Inter-American Development Bank. Washington, DC: IDB.

Ravallion, M. and Dearden, L. (1988). 'Social Security in a "Moral Economy": An Empirical Analysis for Java'. The Review of Economics and Statistics, 70 (1): 36-44.

Scott, J. C. (1976). The Moral Economy of the Peasant: Rebellion and Subsistence in Southeast Asia. New Haven, CT: Yale University Press.

Székely, M. and Rascón, E. (2005). 'México 2000-2002: Reducción de la Pobreza con Estabilidad Económica y Expansión de Programas Sociales', in M. Székely (coordinador), Números Que Mueven Al Mundo: La Medición De La Pobreza En México. Mexico, DF: Miguel Ángel Porrúa.

Teruel, G. and Davis, B. (2000). 'An Evaluation of Impact of Progresa Cash Payments on Private Inter-Household Transfers'. Washington, DC: International Food Policy Research Institute.

Wodon, Q., Angel-Urdinola, D., González-Konig, G., Ojeda Revah, D., and Siaens, C. (2002). 'Migración y pobreza en los estados del sur de México'. Washington, DC: World Bank.

World Bank (2006). Global Economic Prospects: Economic Implications of Remittances and Migration. Washington, DC: World Bank. 